\title{
Complications of peritonsillar abscess
}

\author{
Tejs Ehlers Klug ${ }^{1 *}\left(\mathbb{0}\right.$, Thomas Greve $^{2}$ and Malene Hentze ${ }^{1}$
}

\begin{abstract}
Background: The vast majority of patients with peritonsillar abscess (PTA) recover uneventfully on abscess drainage and antibiotic therapy. However, occasionally patient's condition deteriorates as the infection spread in the upper airway mucosa, through cervical tissues, or hematogenously. The bacterial etiology of PTA is unclarified and the preferred antimicrobial regimen remains controversial. The current narrative review was carried out with an aim to (1) describe the spectrum of complications previously recognized in patients with peritonsillar abscess (PTA), (2) describe the bacterial findings in PTA-associated complications, and (3) describe the time relation between PTA and complications.
\end{abstract}

Methods: Systematic searches in the Medline and EMBASE databases were conducted and data on cases with PTA and one or more complications were elicited.

Results: Seventeen different complications of PTA were reported. The most frequently described complications were descending mediastinitis $(n=113)$, para- and retropharyngeal abscess $(n=96)$, necrotizing fasciitis $(n=38)$, and Lemierre's syndrome $(n=35)$. Males constituted $70 \%$ of cases and $49 \%$ of patients were $>40$ years of age. The overall mortality rate was $10 \%$. The most prevalent bacteria were viridans group streptococci $(n=41,25 \%)$, beta-hemolytic streptococci $(n=32,20 \%)$, F. necrophorum $(n=21,13 \%)$, S. aureus $(n=18,11 \%)$, Prevotella species $(n=17,10 \%)$, and Bacteroides species $(n=14,9 \%)$. Simultaneous diagnosis of PTA and complication was more common (59\%) than development of complication after PTA treatment (36\%) or recognition of complication prior to PTA (6\%).

Conclusion: Clinicians involved in the management of PTA patients should be aware of the wide range of complications, which may arise in association with PTA development. Especially males and patients $>40$ years of age seem to be at an increased risk of complicated disease. In addition to Group A streptococci and F. necrophorum, the current findings suggest that viridans group streptococci, S. aureus, Prevotella, and Bacteroides may also play occasional roles in the development of PTA as well as spread of infection. Complications occasionally develop in PTA patients, who are treated with antibiotics and surgical drainage.

Keywords: Peritonsillar abscess, Complications, Bacteria, Microbiology

\section{Background}

Peritonsillar abscess (PTA) refers to pus collection between the tonsillar capsule and the pharyngeal constrictor muscle. The pathogenesis is unclarified, but closely related to an initial acute tonsillitis and it is likely that bacteria spread to the peritonsillar space via the

\footnotetext{
*Correspondence: tejsehlersklug@hotmail.com

1 Department of Otorhinolaryngology, Head and Neck Surgery,

Aarhus University Hospital, Palle Juul-Jensens Boulevard 99 Aarhus N, Aarhus 8200, Denmark

Full list of author information is available at the end of the article
}

salivary duct system [1]. The incidence of PTA peaks in young adult life (15-19 years: 167 per 100,000 population) [2]. A polymicrobial mixture of aerobes and anaerobes is commonly recovered from pus aspirates, but there is only substantial evidence to suggest pathogenic importance of Group A streptococci and F. necrophorum [3-5]. These two pathogens are commonly recovered in less than $50 \%$ of cases and it seems obvious that more pathogens are involved in PTA development, but the plethora of different bacteria found in an area with heavy bacterial colonization, makes it difficult to pinpoint the

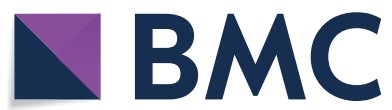

(c) The Author(s) 2020. This article is licensed under a Creative Commons Attribution 4.0 International License, which permits use, sharing, adaptation, distribution and reproduction in any medium or format, as long as you give appropriate credit to the original author(s) and the source, provide a link to the Creative Commons licence, and indicate if changes were made. The images or other third party material in this article are included in the article's Creative Commons licence, unless indicated otherwise in a credit line to the material. If material is not included in the article's Creative Commons licence and your intended use is not permitted by statutory regulation or exceeds the permitted use, you will need to obtain permission directly from the copyright holder. To view a copy of this licence, visit http://creativeco mmons.org/licenses/by/4.0/. The Creative Commons Public Domain Dedication waiver (http://creativecommons.org/publicdomain/ zero/1.0/) applies to the data made available in this article, unless otherwise stated in a credit line to the data. 
pathogenic bacteria from insignificant bystanders [5]. Therefore, the significant pathogens are unclear in the majority of PTA cases.

Treatment of PTA consists of surgical drainage and antimicrobial therapy. There are three accepted methods of drainage: needle aspiration, incision, and acute tonsillectomy. All three methods carry advantages and limitations [5]. Mirroring the unclarified bacterial etiology, the preferred antibiotics vary between centers and multiple regimens have been reported in recent literature [6-8].

Most likely, the vast majority of PTA patients recover uneventfully on abscess drainage and antibiotic therapy. However, the condition of PTA patients occasionally deteriorates as the infection spread in the upper airway mucosa, through cervical tissues, or hematogenously. It is undescribed whether patients with complicated PTA consult health care professionals before the development of complications or if they present with PTA and complication simultaneously. Hence, the proportion of PTA complications, which are potentially preventable, is unexplored.

When searching the literature, we were surprised to acknowledge that no previous attempts for providing a comprehensive review of complications to PTA have been done. Hence, little help was provided for clinicians, who encounter PTA patients with signs of further infectious spread and who requested an overview of this field.

The aims of the current review were threefold:

1. To describe the spectrum of complications previously recognized in PTA patients.

2. To describe the bacterial findings in PTA-associated complications, which may suggest pathogenic importance and be subject to increased attention.

3. To describe the time relation between PTA and complications in order to assess the proportion of complications, which may be avoidable.

\section{Main text}

\section{Materials and methods}

The Medline and EMBASE databases were systematically searched for studies reporting on patients with PTA and complications (see search strings in the Additional file 1: Appendix). Publications after 1980 in English, Danish, and German were considered. The last search was performed June 28, 2020. In addition, an extensive manual search using the reference lists (from articles included) was performed. The searches were conducted by the corresponding author, who also screened titles and abstracts for eligible studies. Final study selection and data extraction were done by the first and last authors. Agreement was reached by consensus. Articles were read with the aim to identify cases with PTA and one or more complications and elicit data describing these cases. No common definition of each complication entity was used, but the inclusion of each article was based on the author's statements concerning the finding of PTA, the defined complication and the (likely) causality. The only exception from this reliance on author's diagnosis, was in the differentiation between cervical necrotizing fasciitis (NF) and descending mediastinitis (DM), which was uniformly untouched in the publications. We categorized patients with described mediastinitis (with or without cervical necrosis) in the DM category and patients with cervical necrosis, but no mediastinitis, in the NF category. Some patients suffered multiple complications. In these cases, patients were categorized according to the complication deemed most severe (order: 1. upper airway obstruction $<$ acute epiglottis $<$ para- and retropharyngeal abscess $<\mathrm{NF}<\mathrm{DM}$. 2. sepsis $<$ Lemierres syndrome (LS)). We excluded complications deemed to be caused by the surgical treatment of PTA (i.e. post-tonsillectomy hemorrhage) and pathology associated with uncomplicated PTA (i.e. velo-pharyngeal insufficiency). For this review, complication was defined as worsening in disease severity or the development of new symptoms or pathological changes, which may become widespread.

Statistical analyses (using STATA 15.1) were performed using the binomial probability test for gender distribution and the Fisher's exact test to compare mortality rates between genders.

\section{Results and discussion Overview}

The literature searches identified 1,047 unique records and 27 records were added from the refence lists (Fig. 1). Through title, abstract, and full-text evaluation 921 records were excluded and 150 records were included in this review.

In total, 334 patients with PTA and one or more associated complications were found in the literature. The most frequently described complications were DM $(n=113)$, para- and retropharyngeal abscess $(n=96), N F(n=38)$ and LS $(\mathrm{n}=35)$ (Table 1). There was a significant male preponderance $(70 \%, \mathrm{p}<0.001$, Binomial probability test) and males outnumbered females in all complication entities with more than two described cases. Information on the time relation between diagnosis of PTA and complication was available in 126 (38\%) cases (Table 1). In these cases, 45 (36\%) patients had PTA prior to development of complication, 74 (59\%) were diagnosed with PTA and complication simultaneously, and in seven (6\%) patients the complication was recognized prior to PTA diagnosis. DM and NF were the most prevalent complications among patients, who had infectious spread after initial 


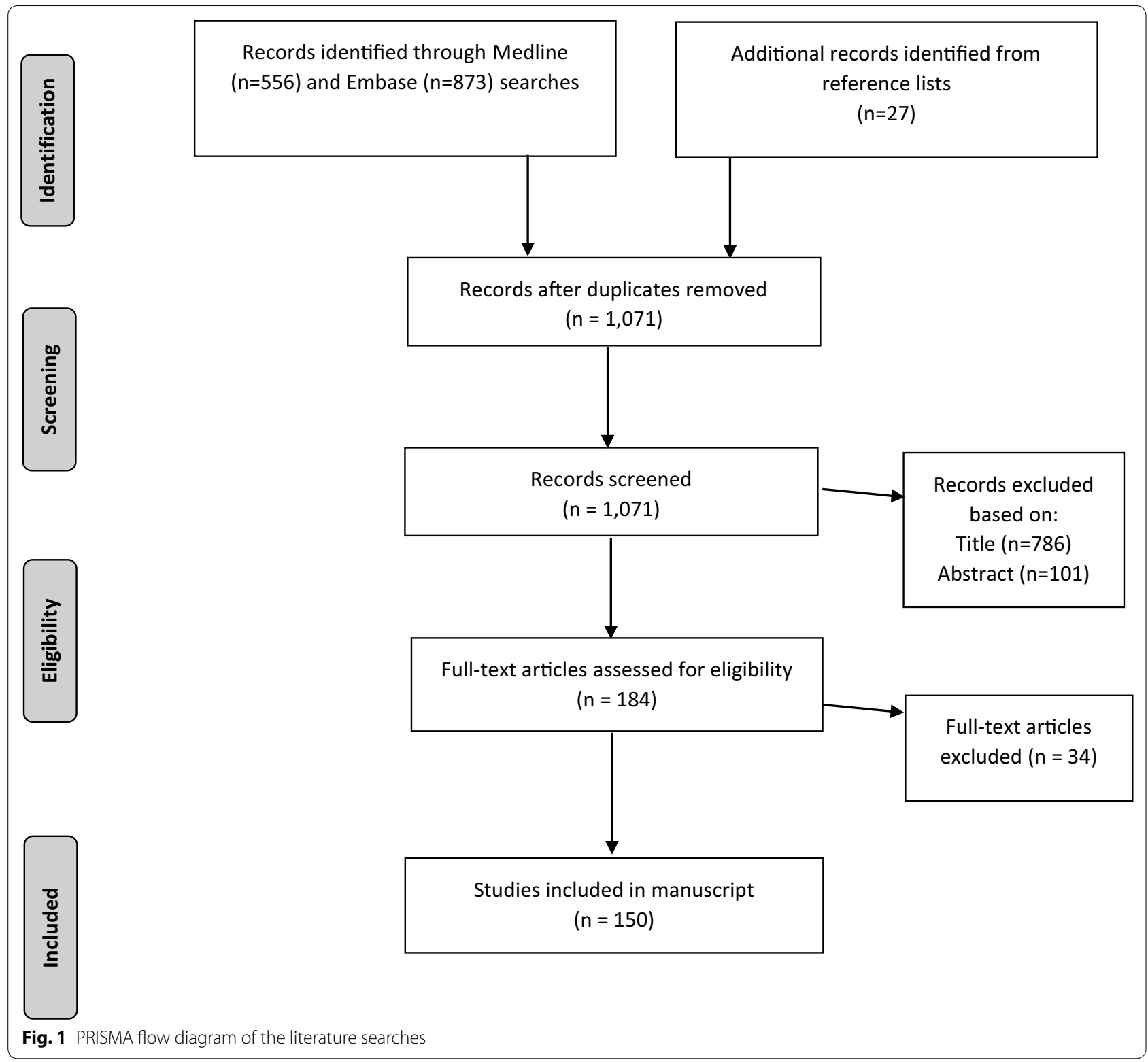

treatment of PTA, but this time relation was also the case in other rare complications (masticator space abscess, reactive arthritis, carditis, and Kawasaki's syndrome). The potential positive effects of aggressive treatment (i.e. acute tonsillectomy and intravenous broad-spectrum antibiotics) compared to more conservative treatment (aspiration/incision and penicillin) could not be estimated due to the limited number and heterogeneity of well-described cases.

The overall mortality rate was $10 \%$ and without significant difference between genders $(p=0.77$, Fishers exact test). With the caveat that information were only available in $29 \%$ and $46 \%$ of cases, respectively, acute tonsillitis prior to PTA development and antibiotic treatment prior to development of complication were prevalent (42\% and 69\%, respectively). These findings suggest that varying standard antibiotic regimens were insufficient to prevent the development or progression of infectious spread. Information regarding microbiologic findings were provided in 162 (49\%) patients (Table 2). The most prevalent bacteria were viridans group streptococci (VGS) $(n=41,25 \%)$, beta-hemolytic streptococci $(\mathrm{n}=32,20 \%$, especially Group A $(\mathrm{n}=20$, $12 \%)$ ), F. necrophorum $(\mathrm{n}=21,13 \%)$, S. aureus $(\mathrm{n}=18$, $11 \%)$, Prevotella species ( $\mathrm{n}=17,10 \%)$, and Bacteroides species $(\mathrm{n}=14,9 \%)$. (Figure 2$)$. In addition to Group A 
Klug et al. Ann Clin Microbiol Antimicrob ～(2020) 19:32

Page 4 of 17

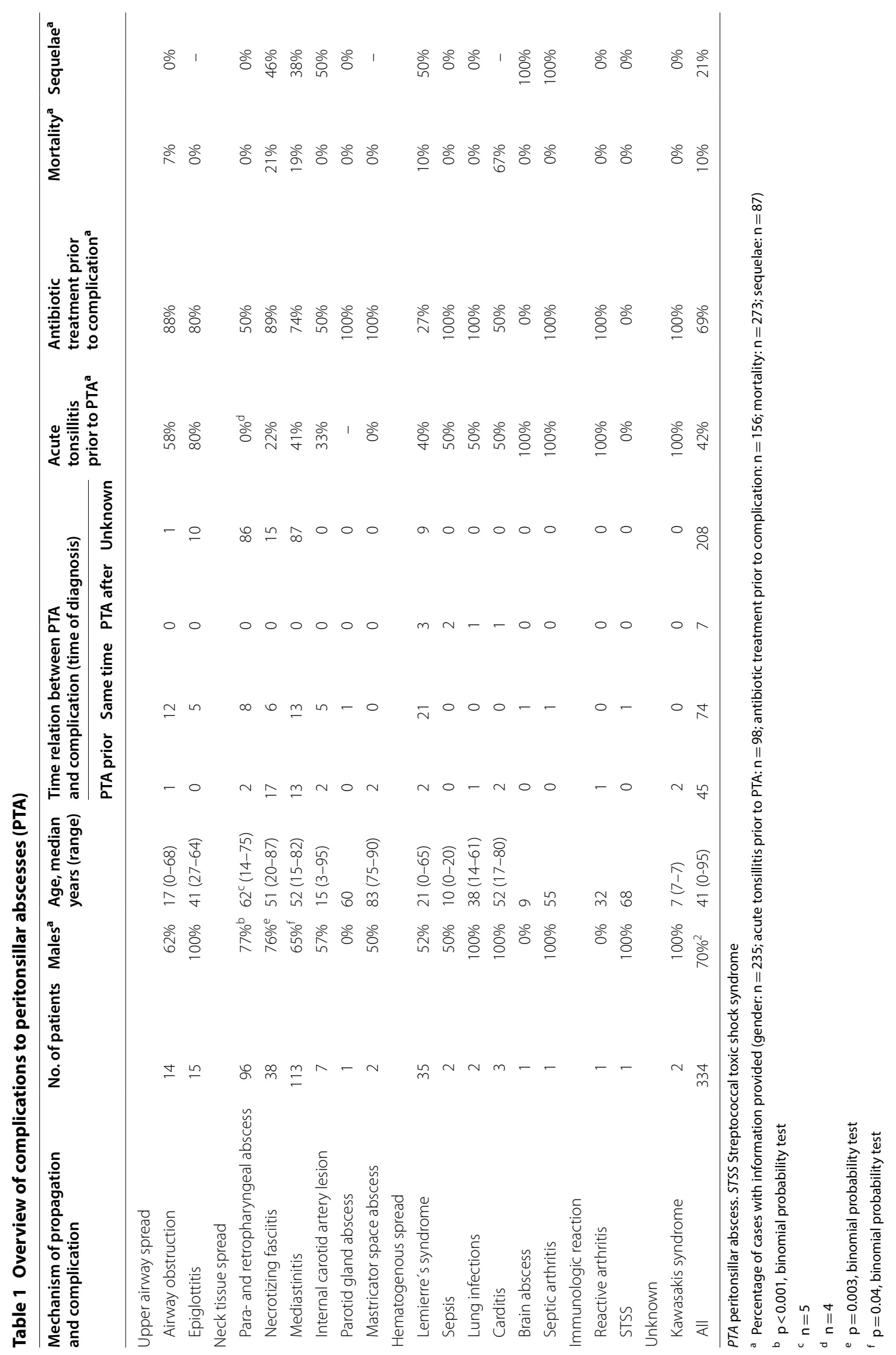


Table 2 Microbiologic findings in 162 patients with peritonsillar abscess and complications

\begin{tabular}{|c|c|c|c|c|c|c|}
\hline Organisms & PPA $n=36$ & LS $n=26$ & $N F n=33$ & $\mathrm{DM} n=46$ & Other $n=21$ & All $n=162$ \\
\hline \multicolumn{7}{|l|}{ Aerobic bacteria } \\
\hline \multicolumn{7}{|l|}{ Streptococcus } \\
\hline Group A & 9 & & 6 & 1 & 4 & 20 \\
\hline Group C & 2 & & 3 & & 2 & 7 \\
\hline Beta-hemolytic & & & 1 & 1 & 2 & 5 \\
\hline Viridans group & 10 & 2 & 10 & 15 & 4 & 41 \\
\hline spp. & & 1 & 2 & 8 & & 11 \\
\hline Enterococcus spp. & & & 2 & & 1 & 3 \\
\hline Staphylococcus aureus & 1 & 2 & 1 & 14 & & 18 \\
\hline Coagulase-negative & & 1 & 6 & 6 & 1 & 14 \\
\hline spp. & & & 4 & & & 4 \\
\hline Haemophilus spp. & 1 & & & 1 & 2 & 4 \\
\hline Enterobacteriales & & & 6 & 4 & 2 & 12 \\
\hline Pseudomonas aeruginosa & & 1 & 1 & 6 & & 8 \\
\hline Burkholderia cepacia & & & & 1 & & 1 \\
\hline Stenotrophomonas maltophilia & & & 1 & & & 1 \\
\hline Corynebacterium spp. & & & 1 & 1 & & 2 \\
\hline Eikenella corrodens & & & & 1 & & 1 \\
\hline Arcano. haemolyticum & & 1 & & & & 1 \\
\hline Neisseria spp. & & 1 & & & & 1 \\
\hline Acinetobacter coloaceticus & & & & 2 & & 2 \\
\hline Moraxella catarrhalis & & & & 1 & & 1 \\
\hline \multicolumn{7}{|l|}{ Anaerobic bacteria } \\
\hline Bacteroides spp. & & 1 & 4 & 9 & & 14 \\
\hline Porphyromonas spp. & & 2 & & & & 2 \\
\hline Prevotella spp. & 1 & 2 & 6 & 5 & 3 & 17 \\
\hline \multicolumn{7}{|l|}{ Fusobacterium } \\
\hline nucleatum & & 2 & 1 & 1 & & 4 \\
\hline necrophorum & 3 & 15 & & 1 & 2 & 21 \\
\hline spp. & & & & 1 & & 1 \\
\hline Peptostreptococcus spp. & & 1 & 5 & 4 & & 10 \\
\hline Peptoniphilus asaccharolyticus & & 1 & & 1 & 1 & 3 \\
\hline Parvimonas micra & & & 1 & & & 1 \\
\hline G+, non-spore-forming bacilli & & & 2 & 3 & & 5 \\
\hline Unspecified anaerobes & 9 & & 2 & 4 & 1 & 16 \\
\hline Unspecified bacteria & & & 3 & 7 & & 10 \\
\hline \multicolumn{7}{|l|}{ Fungi } \\
\hline Candida albicans & 1 & & 3 & 2 & & 6 \\
\hline Aspergillus fumigatus & & & & 1 & & 1 \\
\hline Polymicrobial & $1 / 2$ & $4 / 26$ & $18 / 33$ & $33 / 46$ & $5 / 21$ & $61 / 128$ \\
\hline
\end{tabular}

Bacterial names are reported in contemporary nomenclature (in contrast to Tables 4 and 5)

The names of the following bacteria are merged

Viridans group streptococci: viridans group $(n=16)$, Group $F(n=1)$, non-hemolytic $(n=4)$, mitis group $(n=2)$, sanguis $(n=1)$, salivarius $(n=2)$, intermedius ( $=1)$, constellatus $(n=3)$, anginosus group $(n=4)$, and milleri group $(n=7)$

Enterococcus spp.: E. faecalis $(\mathrm{n}=1)$ and Enterococcus species $(\mathrm{n}=2)$

Coagulase-negative staphylococci: hominis $(n=1)$, epidermidis $(n=6)$, haemolyticus $(n=2)$, and coagulase-negative staphylococci $(n=5)$

Haemophilus spp.: Haemophilus influenza $(\mathrm{n}=3)$ and Haemophilus parainfluenzae $(\mathrm{n}=1)$

Enterobacterales: Escherichia coli $(n=2)$, Enterobacter cloacae $(n=3)$, Enterobacter species $(n=1)$, Klebsiella pneumoniae $(n=2)$, Klebsiella species $(n=1)$, Proteus mirabilis $(n=1)$, Serratia marcescens $(n=1)$, and Citrobacter diversus $(n=1)$

Bacteroides spp.: fragilis $(\mathrm{n}=8)$, and species $(\mathrm{n}=6)$

Prevotella spp.: intermedia $(n=1)$, buccae $(n=1)$, oralis $(n=3)$, corporis $(n=1)$, melaninogenica $(n=6)$, and species $(n=5)$ 
Table 2 (continued)

Peptostreptococcus spp.: Peptostreptococcus anaerobius $(\mathrm{n}=3)$ and Peptostreptococcus species $(\mathrm{n}=7)$

$\mathrm{G}+$, non-spore-forming bacilli: Eggerthella lenta $(n=2)$, Eubacterium species $(n=1)$, Bifidobacterium dentium $(n=1)$, and Eggerthia catenaformis $(n=1)$

Unspecified: Gram-negative rod ( $n=4)$, Gram-negative $(n=1)$, Gram-positive coccus $(n=2)$, Gram-positive rod $(n=1)$, Gram-positive $(n=2)$

PPA parapharyngeal abscess, $L S$ Lemierre's syndrome, $N F$ necrotizing fasciitis, $D M$ descending mediastinitis, Spp species (no further specification was provided in the study), G- Gram-negative, G + Gram-positive, Arcano Arcanobacterium

\section{Diagram of prevalent findings in 162 patients with peritonsillar abscess and complications}

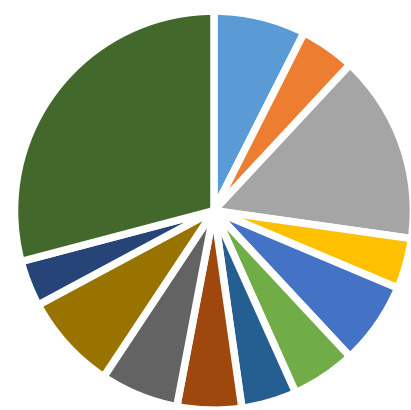

$$
\begin{aligned}
& \text { - Streptococci Group A } \\
& \text { Viridans Group streptococci } \\
& \text { - Staphylococcus aureus } \\
& \text { - Enterobacteriales } \\
& \text { - Prevotella spp. } \\
& \text { - Peptostreptococcus spp. }
\end{aligned}
$$

- Other beta-hemoltytic streptococci

Streptococcus spp.

- Coagulase-negative staphylococci

- Bacteroides spp.

- Fusobacterium necrophorum

- Other

Fig. 2 Diagram of the prevalent findings in 162 patients with peritonsillar abscess and complications

streptococci and F. necrophorum, the current findings suggest that VGS, S. aureus, Prevotella, and Bacteroides may also play an occasional role in the development of PTA as well as spread of infection. However, a plethora of potential pathogens, both aerobes and anaerobes, were recovered from PTA pus, sites of complication, blood, or unspecified sites (unfortunately the sites for culture were undescribed in the majority of cases). Hence, our findings support previous studies that PTAs and complications of PTA can be caused by multiple pathogens and infections are often polymicrobial $(48 \%$, Table 2). While some of the prevalent pathogens were almost exclusively found in one or two complication entities (S. aureus: DM; F. necrophorum: LS), streptococci were more evenly distributed among complications with the exception of LS (Table 2).

\section{Spread of infection in the upper airways Upper airway obstruction}

Upper airway obstruction may develop because of large abscess volume(s), tonsillar hypertrophy, and/ or collateral mucosal edema or phlegmon of the pharynx and larynx. Eleven case reports described a total of twelve patients with PTA and upper airway obstruction without additional abscesses, epiglottitis, DM, or NF [9-19]. Patients characteristics, their treatment, and microbial findings are presented in Table 3. The majority of patients were diagnosed with (58\%) and treated for (50\%) acute tonsillitis prior to PTA diagnosis (mean 2.7 days). Streptococci were recovered from six of seven patients from whom bacterial cultures were performed. The site of upper airway obstruction was the oropharynx in $83 \%$ of cases and developed after PTA treatment (incision and drainage) in only one case (8\%). Acute airway management 


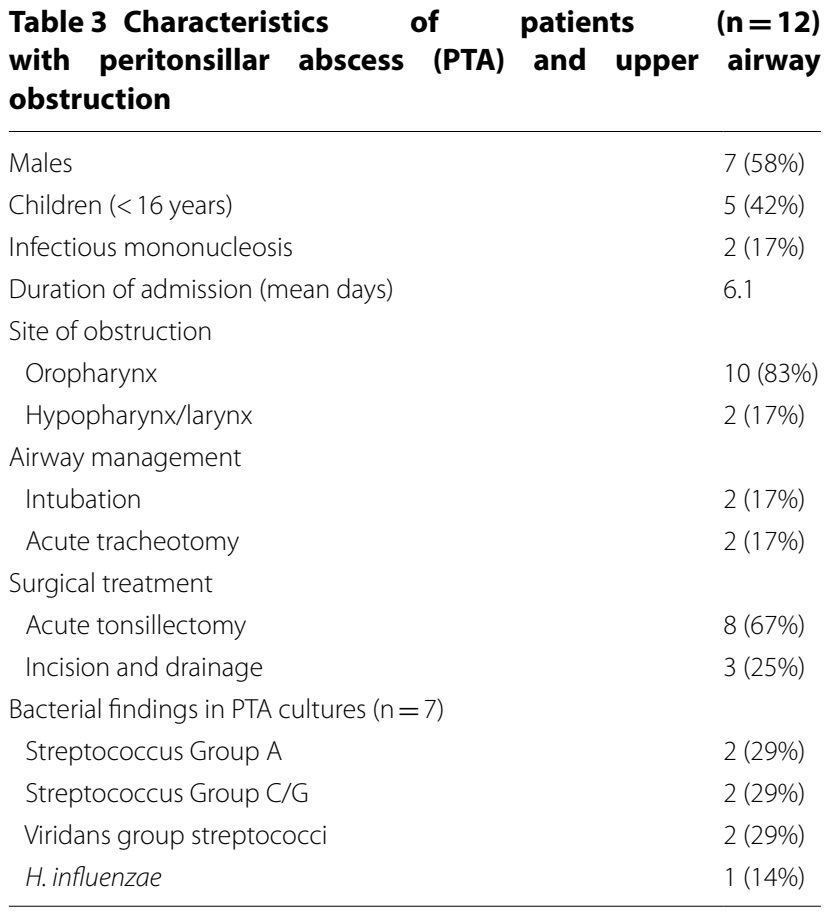

was performed in four patients and one $(8 \%)$ patient died before reaching hospital. No other sequelae were described. The antibiotic regimens were different from each other in all eight cases with this information provided. In addition to the twelve well-described cases, Hsiao et al. and Menezes et al. each reported a case of upper airway obstruction among 56 and 71 children with PTA, respectively $[20,21]$.

\section{Acute epiglottitis}

Five patients with concomitant PTA and acute epiglottitis have been described in two papers [22, 23]. All patients were adult males (age range 27-64 years) and four patients were treated with antibiotics because of acute tonsillitis prior to epiglottitis and PTA diagnoses. None of the patients underwent surgical treatment of the PTA and, hence, no PTA culture results were reported. All patients recovered on different regimens of broad-spectrum antibiotics. In addition to the five well-described cases, Brandow reported four cases of concomitant epiglottitis among 156 PTA patients undergoing acute tonsillectomy [24]. Hafidh et al. described 10 adult cases of acute epiglottitis and found one patient with concurrent PTA [25]. Lastly, five cases of "epiglottis involvement" among 45 PTA patients with concomitant para- or retopharyngeal abscess were reported by Monobe et al. [26].
Spread of infection through neck tissues Para- and retropharyngeal abscess/phlegmon

Infections laterally or posteriorly to the pharyngeal constrictor muscle are referred to as para- and retropharyngeal abscess or phlegmon. These infections may arise after spread of bacteria from the teeth or upper airway mucosa through neck tissues or lymph ducts [27, 28]. Less frequently, para- and retropharyngeal infections are described as extensions of PTA [20, 26, 29-37]. In a study of 99 PTA patients by Kawabata et al., thirteen patients had spread of infection into the para- and/or retropharyngeal spaces [36]. Two pediatric studies reported concurrent PTA and para- or retropharyngeal abscess in $2 / 249$ and $2 / 56$ patients, respectively $[20,29]$. In the latter study, all patients were treated with antibiotics only [20]. Monobe et al. stratified 45 patients with PTA and either para- or retropharyngeal abscess into superior $(n=24)$ and inferior types $(n=21)$ according to the location of the PTA [26]. The majority of superior PTAs were aspirated or incised while inferior PTAs underwent intraoral drainage $(n=14)$ or no surgery $(n=10)$. Page et al. included 31 patients undergoing immediate tonsillectomy because of either PTA $(n=13)$, parapharyngeal abscess $(n=13)$, or concomitant PTA and parapharyngeal abscess $(n=5)$ [30]. Côrte et al. reported four cases of PTA progressing to parapharyngeal abscess $(n=2)$ or retropharyngeal abscess $(n=2)$ [34]. Similarly, Ohori et al. described three cases of PTA and concurrent parapharyngeal abscess (one case had an additional submandibular space abscess) [35].

Information on bacterial findings were only included in three studies [31, 32, 35]. In a study of 63 patients with parapharyngeal abscess, cultures were performed in 32 of 33 patients with concomitant PTA [32]. The most common findings were Group A streptococci (29\%), VGS (18\%), F. necrophorum (12\%), and Group C/G streptococci (12\%). Treatment included acute tonsillectomy (33/33) and internal incision (32/33). Ohori et al. also advocated for acute tonsillectomy and internal incision based on the outcomes of three patients with concomitant PTA and parapharyngeal abscess [35]. Bacterial examinations showed Streptococcus constellatus + Prevotella melaninogenica, no growth, and S. constellatus, respectively. A 24-years old woman with Group A streptococci in blood cultures were surgically treated for bilateral PTA with extension into the right parapharyngeal space 1 day after undergoing PTA needle aspiration [31]. Except one patient in the case series by Ohori et al., who refused acute tonsillectomy and subsequently developed submandibular space abscess, all other studies reported that patients recovered without further spread of infection. Hence, multiple management regimes seemed to clear the infection (surgically and antibiotically). 


\section{Necrotizing fasciitis (NF)}

$\mathrm{NF}$ is a rapidly progressing infection that typically involves necrosis of the superficial tissue layers but may extend to the deep fat and fascial layers [38]. The most common primary sites of infection in cervical NF are the teeth, the tonsils, and traumatic or surgical wounds [39, 40]. In a previous review of cervical NF $(n=13)$, Boninsegna et al. found a higher mortality rate in PTA-associated NF (31\%) compared to NF of other origins (20\%) and that patients treated with tonsillectomy had a better prognosis ( $0 \%$ mortality rate) compared to cases treated without tonsillectomy $(44 \%$ mortality rate $)(\mathrm{p}=0.056)$ [41]. In total, 38 cases (median age 51 years) of PTAassociated cervical NF were found (Table 1) [37, 41-66]. Significantly more males ( 26 cases) than females ( 8 cases) were described ( $\mathrm{p}=0.003$, Binomial probability test). A wide variety of bacteria were found with streptococci and staphylococci being the most prevalent strains (Table 4). Multiple bacterial species were recovered in 55\% (18/33) of cultures. Great variations in treatment modalities were found among the 17 patients, who were diagnosed with PTA prior to NF development, both concerning the surgery performed and choices of antibiotics (Table 4). The mortality rate was $12 \%(2 / 17)$ in this group compared to $50 \%(3 / 6)$ in the group of patients, who were diagnosed with PTA and NF simultaneously, and 18\% (2/11) in patients with no information regarding this time relation. The number of patients are too small to draw conclusions concerning the effects of different treatment modalities on the risk of death.

\section{Descending mediastinitis (DM)}

Cervical infections originating from PTAs may descend through the cervical planes to the mediastinum. Pneumonia, pleural effusion and empyema, shock, acute respiratory distress syndrome (ARDS), disseminated intravascular coagulation (DIC), and other complications are frequently present in association with DM.

We found 38 studies reporting a total of 113 patients with PTA-associated DM [67-104]. The median age was 52 years and there was a significant male preponderance $(65 \%, 34 / 52, \mathrm{p}=0.04$, Binomial probability test). The mortality rate was $19 \%$. Forty-four cases were welldescribed and are presented in Table 5 . A wide variety of bacteria were recovered from PTA pus, cervical tissues, mediastinum, or blood (Tables 2 and 5). Like PTA-associated NF, great variations in treatment modalities were found among the 13 patients, who were diagnosed with PTA prior to DM development (Table 5). No difference in mortality rates (both $8 \%, 1 / 13$ ) was found between patients diagnosed with PTA prior to DM development and patients with simultaneous PTA and NF, but the mortality was $28 \%(5 / 18)$ among patients with no information concerning this time relation. From the limited number of patients, we are unable to estimate if aggressive eradication of the peritonsillar infection or broad-spectrum antibiotics reduce the risk of DM or improve the outcome compared to less comprehensive treatment.

\section{Internal carotid artery lesion}

Bacteria may spread to the internal carotid artery from a PTA resulting in vascular necrosis $[105,106]$ or (pseudo-) aneurysm [107-111]. PTA-associated carotid artery lesions were occasionally reported in the preantibiotic era [106], but we only found seven described cases within the last 40 years [105-111]. In addition to symptoms of PTA, some patients presented with intermittent severe hemorrhage $(n=2)$ and anisocoria $(n=1)[105,106]$. In two cases, a bleeding pseudoaneurysm developed 35-45 days after PTA drainage [107, 109], while the PTA and the carotid artery lesion were diagnosed simultaneously in five cases $[105,106,108,110,111]$. Four patients were children (3-15 years of age) and two patients were elderly (65 and 95 years of age, respectively). The bacterial findings in PTA specimens were only described in two cases [109, 111]: streptococcus Group A $(n=1)$ and VGS $(n=1)$. Ligation or embolization of the internal carotid artery was carried out in all but one patient (who underwent stenting) [108]. All patients survived, but sequelae were described in three cases: Horners syndrome $(\mathrm{n}=3)$ and discrete contralateral neurological deficit $(\mathrm{n}=1)[106,109,110]$.

\section{Parotid gland abscess}

Reiss and Reiss described a 60-year-old female, who was diagnosed with concomitant bilateral PTA and unilateral parotid gland abscess [112]. PTA cultures grew Klebsiella pneumoniae. The patient recovered after acute tonsillectomy, external cervical incision, and ciprofloxacin therapy.

\section{Masticator space abscess}

Hidaka et al. described two cases of PTA and masticator space abscess in a 75-year-old man and a 90-year-old woman [113]. Both patients recovered without sequelae after intensive antibiotic therapy, incision of the PTA, and drainage of the masticator space abscess. PTA pus cultures grew Prevotella corporis + Gemella morbillorum and peptostreptococcus species, respectively.

\section{Hematogenous spread of infection Lemierre's syndrome (LS)}

The sequence of events leading from (peri-)tonsillar infection to LS is not fully understood. A key step is spread of bacteria from the tonsil to the internal jugular 
Table 4 Characteristics of 34 well-described patients with peritonsillar abscess (PTA) and necrotizing fasciitis (NF)

\begin{tabular}{|c|c|c|c|c|c|c|}
\hline \multirow[t]{2}{*}{ References } & \multirow[t]{2}{*}{ Age (years) } & \multirow[t]{2}{*}{ Gender } & \multirow[t]{2}{*}{ Microbiologic findings } & \multicolumn{2}{|c|}{$\begin{array}{l}\text { Treatment of PTA prior to NF } \\
\text { development }\end{array}$} & \multirow[t]{2}{*}{ Outcome } \\
\hline & & & & Surgery & Antibiotics & \\
\hline Wills [42] & 35 & M & S. maltophilia;VGS; B. melaninogenicus & Spon perf & Iv. pen & Survived \\
\hline Wenig [43] & 50 & M & $\begin{array}{l}\text { AHS; F. nucleatum; E. lentum; B. melaninogenicus; P. } \\
\text { anaerobius; E. cloacae; S. epidermidis; Klebsiella } \\
\text { spp.; P. aeruginosa }\end{array}$ & Simultaneous ${ }^{a}$ & & Died \\
\hline Wenig [63] & 50 & M & $\begin{array}{l}\text { AHS; E. coli; mitis group strep.; S. san-guis; S. faecalis; } \\
\text { B. fragilis; B. mela-ninogenicus; Corynebacterium } \\
\text { spp. }\end{array}$ & Incision & Iv. cefazolin & Died \\
\hline Pedersen [37] & 67 & M & No cultures & Simultaneous ${ }^{a}$ & & Died \\
\hline Lalwani [44] & 33 & M & GCS; B. melaninogenicus & Incision & Im. pen & Survived \\
\hline Tovi [43] & 20 & M & Enterobacter spp.; P. mirabilis; K. pneumoniae & $\mathrm{Nl}^{\mathrm{b}}$ & & Died \\
\hline Scott [46] & 51 & M & Milleri group strep; NHS; anaerobes & Drainage & Iv. cefo, fluclo, metro & Survived \\
\hline Maisel [50] & 29 & M & VGS & $\mathrm{Nl}^{\mathrm{b}}$ & & Survived \\
\hline Jackson [47] & 63 & M & E. lentum; P. anaerobius; $B$. fragilis & Drainage & None & Survived \\
\hline Greinwald [45] & 65 & M & GAS; S. epidermidis & Incision & Iv. ampicillin & Survived \\
\hline Hadfield [48] & 53 & M & GCS; Bacteroides spp. & Incision & IV. cefo, metro & Survived \\
\hline Skitalic [51] & 50 & $\mathrm{~F}$ & S. epidermidis; (GAS antibodies) & Simultaneous ${ }^{\mathrm{a}}$ & & Survived \\
\hline Djupesland [52] & 39 & M & GAS & Simultaneous ${ }^{\mathrm{a}}$ & & Died \\
\hline Djupesland [52] & 36 & M & Milleri group strep.; Bacteroides spp. & Asp & Iv. pen, tobra, metro & Survived \\
\hline Nielsen [58] & $\mathrm{NI}$ & $\mathrm{NI}$ & GCS & $\mathrm{Nl}^{\mathrm{b}}$ & & Died \\
\hline Safak [49] & 43 & $\mathrm{~F}$ & GAS; CNS; Enterococci & Drainage & Iv. pen, im. chlor & Survived \\
\hline Goldenberg [53] & 53 & $\mathrm{~F}$ & $\mathrm{BHS}$ & Incision & IV. pen $\rightarrow$ pip-tazo & Survived \\
\hline Vaid [61] & 55 & M & GAS & Simultaneous ${ }^{\mathrm{a}}$ & & Survived \\
\hline Beninsegna [41] & 58 & M & S. epidermidis & Acute tons & Iv. ampicillin, metro & Survived \\
\hline Beninsegna [41] & 80 & M & GAS; Peptostreptococcus spp.; C. albicans & Incision & Iv. ampicillin, metro & Survived \\
\hline Losanoff [54] & 54 & M & NHS; Peptostreptococcus spp. & No & Iv. ceftriaxo-ne, amoxicillin & Survived \\
\hline Bono [55] & 60 & M & No cultures & Spon perf & IV. ceftriaxo-rine, metro & Died \\
\hline Wolf [57] & 62 & M & GAS & $\mathrm{Nl}^{\mathrm{b}}$ & & Survived \\
\hline Wolf [57] & 49 & M & NHS & $\mathrm{Nl}^{\mathrm{b}}$ & & Survived \\
\hline Andres [56] & 87 & $\mathrm{~F}$ & Staphylococci & $\mathrm{Nl}^{\mathrm{b}}$ & & Survived \\
\hline Andres [56] & 64 & $\mathrm{~F}$ & Staphylococci; Gram-negative rod & $\mathrm{Nl}^{\mathrm{b}}$ & & Survived \\
\hline Andres [56] & 44 & M & Staphylococci; Gram-negative rod; C. albicans & $\mathrm{Nl}^{\mathrm{b}}$ & & Survived \\
\hline Andres [56] & 44 & M & Staphylococci; Gram-negative rod; C. albicans & $\mathrm{Nl}^{\mathrm{b}}$ & & Survived \\
\hline Horváth [59] & 55 & M & No bacterial growth & $\mathrm{Nl}^{\mathrm{b}}$ & & Survived \\
\hline Horváth [59] & 61 & $\mathrm{~F}$ & Parvimonas micra & $\mathrm{NI}^{\mathrm{b}}$ & & Survived \\
\hline Flores [62] & 38 & M & S. constellatus, Peptostreptococcus spp., Prevotella spp. & Simultaneous ${ }^{a}$ & & Survived \\
\hline Brown [64] & 56 & M & Prevotella spp; CNS & Incision & Clindamycin & Survived \\
\hline Irani [66] & 33 & M & S. aureus & Incision & Iv. antibiotics & Survived \\
\hline Burstin [65] & 47 & $\mathrm{~F}$ & Milleri group strep.; anaerobes & No & IV. antibiotics & Survived \\
\hline
\end{tabular}

Bacterial names are written as reported by author (and not changed according to current nomenclature)

VGS viridans group streptococci, Spon perf spontaneous perforation, Pen penicillin, Iv Intravenous, Strep streptococci, Im intramuscular, Cefo cefotaxime, Fuclo flucloxacillin, AHS alpha-hemolytic streptococci, GCS Group C streptococci, NHS non-hemolytic streptococci, CNS coagulase-negative staphylococci, BHS betahemolytic streptococci, GAS Group A streptococci, Asp aspiration, Tobra tobramycin, Chlor chloramphenicol, Pip-tazo piperacillin-tazobactam, Tons tonsillectomy

a Simultaneous diagnosis and treatment of PTA and NF

b No information regarding the time relation between PTA and NF

vein, which could be hematogenous via the tonsillar veins or direct spread. According to Riordan, histological observations in the pre-antibiotic era showed abscesses in the proximity of the tonsil in patients with LS, and bacteria were thought to spread from these abscesses deeper into the loose connective tissue of the pharynx and attach to the walls of the veins [114]. 
Table 5 Characteristics of 44 well-described patients with peritonsillar abscess (PTA) and descending mediastinitis (DM)

\begin{tabular}{|c|c|c|c|c|c|c|}
\hline \multirow[t]{2}{*}{ References } & \multirow[t]{2}{*}{ Age (years) } & \multirow[t]{2}{*}{ Gender } & \multirow[t]{2}{*}{ Microbiologic findings } & \multicolumn{2}{|c|}{$\begin{array}{l}\text { Treatment of PTA prior to DM } \\
\text { development }\end{array}$} & \multirow[t]{2}{*}{ Outcome } \\
\hline & & & & Surgery & Antibiotics & \\
\hline Zgheib [89] & 52 & M & Group A streptococci, E. corrodens & Drain & Ery $\rightarrow$ Clinda & Survived \\
\hline Civen [74] & 45 & M & $\begin{array}{l}\text { C. diversus, Group F streptococci, VGS, CNS, P. } \\
\text { bucca, P. intermedia, F. nucleatum, A. odontolyti- } \\
\text { cus, B. dentium, L. catenaforme, P. anaerobius, P. } \\
\text { asaccharolyticus }\end{array}$ & Simultaneous ${ }^{a}$ & & Survived \\
\hline Alsoub [75] & 32 & M & VGS & Incision & Cephalothin & Survived \\
\hline Alsoub [75] & 47 & M & Negative cultures & Incision & Cephalothin & Survived \\
\hline Cordero [88] & 27 & M & S. anginosus, anaerobes & Incision & None & Survived \\
\hline Nielsen [91] & 25 & M & S. anginosus, Bacteroides spp. & Acute tons & Iv. pen + metro & Survived \\
\hline Endo [93] & 67 & M & $\begin{array}{l}\text { Peptostreptococcus sp., C. albicans, Gram-positive } \\
\text { coccus }\end{array}$ & Simultaneous ${ }^{\mathrm{a}}$ & & Survived \\
\hline Endo [93] & 63 & $\mathrm{~F}$ & $\begin{array}{l}\text { Gram-positive coccus + Gram-positive } \\
\text { rod + Gram-negative rod }\end{array}$ & Simultaneous $^{\mathrm{a}}$ & & Survived \\
\hline Manecke [96] & 29 & M & $\begin{array}{l}\text { Beta-hemolytic streptococci, Pepto-streptococcus } \\
\text { spp., Bacteroides spp. }\end{array}$ & Simultaneous $^{\mathrm{a}}$ & & Survived \\
\hline Corsten [99] & 71 & M & Gram-positive bacilli & No & Clinda & Survived \\
\hline Sancho [76] & 19 & $\mathrm{~F}$ & A. coloaceticus, P. aeruginosa, B. fragilis & $\mathrm{NI}^{\mathrm{b}}$ & & Survived \\
\hline Sancho [76] & 71 & M & S. aureus, E. cloacae, B. fragilis & $\mathrm{NI}^{\mathrm{b}}$ & & Died \\
\hline Sancho [76] & 39 & M & S. aureus, P. aeruginosa, B. fragilis & $\mathrm{NI}^{\mathrm{b}}$ & & Survived \\
\hline Laxmipathi [90] & 70 & M & S. aureus & Drain & $\mathrm{Nl}$ & Survived \\
\hline Asrar [97] & 36 & M & Non-hemolytic streptococci & Incision & Iv. Unspec & Survived \\
\hline Lautermann [77] & 52 & $\mathrm{NI}$ & $\mathrm{AHS}, \mathrm{CNS}$ & Simultaneous ${ }^{a}$ & & Survived \\
\hline Lautermann [77] & 61 & $\mathrm{NI}$ & Negative cultures & Simultaneous ${ }^{\mathrm{a}}$ & & Survived \\
\hline Mihos [78] & 26 & M & S. hominis, Fusobacterium spp. & Drain & Unspec & Survived \\
\hline Collin [79] & 48 & M & S. salivarius & Incision & Amox-clav + metro & Survived \\
\hline Sandner [80] & 26 & M & AHS, N. catarrhalis, C. albicans & Simultaneous $^{1}$ & & Survived \\
\hline Sandner [80] & 45 & M & AHS, VGS, S. aureus, S. marcescens & Drain & Unspec & Died \\
\hline Roccia [68] & 65 & M & S. anginosus & $\mathrm{Nl}{ }^{\mathrm{b}}$ & & Survived \\
\hline Roccia [68] & 50 & M & S. epidermidis, B. melaninogenicus & $N l^{b}$ & & Died \\
\hline Roccia [68] & 53 & M & Negative cultures & $\mathrm{NI}^{\mathrm{b}}$ & & Died \\
\hline Roccia [68] & 20 & M & S. aureus & $\mathrm{Nl}^{\mathrm{b}}$ & & Survived \\
\hline Roccia [68] & 37 & $\mathrm{~F}$ & S. aureus & $\mathrm{NI}^{\mathrm{b}}$ & & Survived \\
\hline Roccia [68] & 16 & $\mathrm{~F}$ & S. anginosus & $\mathrm{Nl}{ }^{\mathrm{b}}$ & & Survived \\
\hline Roccia [68] & 58 & M & S. aureus, A. fumigatus & $\mathrm{NI}{ }^{b}$ & & Survived \\
\hline Roccia [68] & 52 & M & VGS, Prevotella oralis & $\mathrm{NI}^{\mathrm{b}}$ & & Died \\
\hline Roccia [68] & 33 & $\mathrm{~F}$ & H. influenzae & $\mathrm{Nl}{ }^{\mathrm{b}}$ & & Survived \\
\hline Roccia [68] & 65 & M & S. aureus & $N l^{b}$ & & Survived \\
\hline Roccia [68] & 66 & M & S. epidermidis, $P$. aeruginosa & $\mathrm{Nl}{ }^{\mathrm{b}}$ & & Survived \\
\hline Roccia [68] & 57 & M & S. haemolyticus, B. cepacia & $\mathrm{Nl}^{\mathrm{b}}$ & & Died \\
\hline Roccia [68] & 58 & $\mathrm{~F}$ & S. aureus & $\mathrm{NI}^{\mathrm{b}}$ & & Survived \\
\hline Roccia [68] & 53 & M & VGS, P. aeruginosa & $\mathrm{NI}^{\mathrm{b}}$ & & Survived \\
\hline Kinzer [81] & 67 & $\mathrm{NI}$ & S. intermedius, Bacteroides spp. & Simultaneous ${ }^{a}$ & & Died \\
\hline De Freitas [83] & 18 & $\mathrm{~F}$ & $\mathrm{Nl}$ & Simultaneous $^{\mathrm{a}}$ & & Survived \\
\hline De Freitas [83] & 30 & $\mathrm{~F}$ & $\mathrm{Nl}$ & Incision & Unspec & Survived \\
\hline Nakamura [100] & 77 & $\mathrm{~F}$ & Bacteroides spp., Corynebacterium spp. & Simultaneous ${ }^{\mathrm{a}}$ & & Survived \\
\hline Anderson [102] & $\mathrm{NI}$ & $\mathrm{F}$ & VGS & Simultaneous ${ }^{\mathrm{a}}$ & & Survived \\
\hline lyer [94] & 74 & M & Gram-positive, Gram-negative, anaerobes & Simultaneous $^{\mathrm{a}}$ & & Survived \\
\hline Gallo [98] & 57 & M & S. aureus (MR) & $\mathrm{Nl}^{\mathrm{b}}$ & & Survived \\
\hline Wahab [95] & 29 & $\mathrm{~F}$ & Negative cultures & Asp & Pen + metro $\rightarrow$ clari + metro & Survived \\
\hline
\end{tabular}


Table 5 (continued)

\begin{tabular}{|c|c|c|c|c|c|}
\hline \multirow[t]{2}{*}{ References } & \multirow[t]{2}{*}{ Age (years) } & \multirow[t]{2}{*}{ Gender } & \multirow[t]{2}{*}{ Microbiologic findings } & $\begin{array}{l}\text { Treatment of PTA prior to DM } \\
\text { development }\end{array}$ & \multirow[t]{2}{*}{ Outcome } \\
\hline & & & & Antibiotics & \\
\hline Geerts [82] & 34 & M & S. aureus, S. salivarius, F. necrophorum & Simultaneous ${ }^{a}$ & Survived \\
\hline \multicolumn{6}{|c|}{ Bacterial names are written as reported by author (and not changed according to current nomenclature) } \\
\hline \multicolumn{6}{|c|}{$\begin{array}{l}M \text { male, } F \text { female, Drain drainage, Ery erythromycin, } \rightarrow \text { changed to, Clinda clindamycin, VGS Viridans group streptococci, CNS Coagulase-negative staphylococci, Tons } \\
\text { tonsillectomy, IV intraveneous, Pen penicillin, Metro metronidazole, NI no information, Unspec unspecified, AHS alpha-hemolytic streptococci, Amox-clav amoxicillin- } \\
\text { clavulanate, MR Methicillin resistant, Asp: aspiration, Clari clarithromycin }\end{array}$} \\
\hline \multicolumn{6}{|c|}{ a Simultaneous diagnosis and treatment of PTA and DM } \\
\hline
\end{tabular}

In total, our literature search identified 35 described cases (median age 21 years) of PTA and LS [115-142]. Ten patients $(40 \%)$ were diagnosed with acute tonsillitis and seven patients were treated with antibiotics for a mean of 4.8 days prior to PTA and LS development (Table 1). The time relation between PTA and LS was described in 26 cases: 21 patients were diagnosed with PTA and LS simultaneously; two patients were treated for PTA prior to LS development, and in three patients LS was diagnosed prior to PTA recognition. There was a slight male preponderance $(52 \%, 13 / 25)$. The mortality rate was $10 \%(3 / 31)$ and sequelae were described in four cases. The microbiological findings were reported in 26 cases (Table 6). The bacterial findings in PTA aspirates were only reported in five cases and only two cases described coherent findings in PTA aspirates and blood cultures (S. aureus and F. necrophorum, respectively) $[126,141]$. The frequent observation of preceding acute tonsillitis, the common simultaneous diagnosis of PTA and LS, and the lack of knowledge concerning the bacteria involved in the presented PTA cases, raise the question if development of LS is a complication of the initial acute tonsillitis or secondary to the PTA.

Compared to acute tonsillitis, LS seems less frequently associated with PTA. Hagelskjaer-Kristensen et al. found two patients with LS and PTA compared to 35 patients

Table 6 Microbiological findings in 26 patients with peritonsillar abscess (PTA) and Lemierre's syndrome

\begin{tabular}{|c|c|c|c|c|}
\hline \multirow[b]{2}{*}{ Bacteria } & \multicolumn{4}{|l|}{ Culture site } \\
\hline & PTA $(n=5)$ & Blood $(n=18)$ & Liver abscess $(n=1)$ & $\begin{array}{l}\text { Unknown } \\
(n=3)\end{array}$ \\
\hline \multicolumn{5}{|l|}{ Aerobes } \\
\hline Alpha-hemolytic streptococci & 1 & & & \\
\hline Viridans group streptococci & & 1 & & 1 \\
\hline Staphylococcus aureus & 1 & 1 & & \\
\hline Coagulase-negative staphylococci & 1 & & & \\
\hline Arcanobacterium haemolyticum & & 1 & & \\
\hline Pseudomonas aeruginosa & & & & 1 \\
\hline Neisseria spp. & & & & 1 \\
\hline \multicolumn{5}{|l|}{ Anaerobes } \\
\hline Fusobacterium necrophorum & 1 & 14 & 1 & \\
\hline Fusobacterium nucleatum & 1 & 1 & & \\
\hline Prevotella spp. & 2 & & & \\
\hline Porphyromonas spp. & 1 & 1 & & \\
\hline Bacteroides spp. & & & & 1 \\
\hline Peptostreptococcus spp. & & & & 1 \\
\hline Peptoniphilus asaccharolyticus & & 1 & & \\
\hline
\end{tabular}

The names of the following bacteria are merged

Viridans group streptococci: milleri group $(n=1)$ and Streptococcus constellatus $(n=1)$

Spp species 
with LS and acute tonsillitis [135]. In a study of eleven cases of LS (with oropharyngeal origin) by Rhigini et al., six patients had PTA [117]. Based on the multiple cases described in literature, most patients seem to develop LS without evidence of PTA, PPA, or other deep neck abscesses or phlegmon. However, patients with concomitant LS and PTA may be underestimated as most patients diagnosed with LS were never examined by an otorhinolaryngologist and some patients may have had smaller, undiagnosed PTAs, which subsided during the massive antibiotic treatment. In this regard, it is noteworthy that the primary causative bacteria in LS, F. necrophorum, can be recovered more frequently in PTA patients (up to 60\% among teenagers) than patients with acute tonsillitis (1248\%) $[143,144]$.

\section{Sepsis}

We found two described cases: A 20-year-old male developed pericardial effusion, acute respiratory failure, and sepsis some days after treatment of a sore throat with azithromycin $[145,146]$. Blood cultures grew F. necrophorum, but there were no signs of internal jugular vein thrombosis. After some days with broad-spectrum antibiotic treatment, a CT angiogram revealed a PTA, which was drained. No information on sequelae was provided. A 3-month-old girl with congenital bone marrow failure developed septic shock, but recovered after drainage of PTA and broad-spectrum antibiotic treatment [147]. No microorganisms were identified.

\section{Lung infections}

Two cases of PTA and lung complications without DM were described [148, 149]. A 14-year-old male was admitted with concomitant PTA, cervical phlegmon and lung abscesses [149]. F. necrophorum was found in cervical pus specimens. Apart from pus aspiration, no surgical intervention was performed. Nevertheless, he recovered without sequelae on antibiotics. A 61-year-old male with an undrained PTA (for 2 days) developed parapharyngeal space infection, bilateral pleural effusion, and dorsal lung collapse [148]. PTA cultures grew beta-hemolytic streptococci and anaerobic rods. He underwent unspecified surgery and received broad-spectrum antibiotics. No information regarding sequelae was provided.

\section{Carditis}

We found three described cases of PTA complicated by carditis. A 58-year-old male experienced spontaneous perforation of a PTA (treated with intravenous penicillin) the day after receiving amoxicillin because of progressive sore throat [150]. The following day the patient died from myocarditis. E. coli and Enterococci were recovered from pericardium fluid, while normal flora was found in tonsillar cultures. A 17-year-old male had cardiac arrest a few hours after quinsy tonsillectomy [151]. His death 12 days later was deemed to be caused by the pancarditis found at autopsy. No bacterial findings were reported. An 80-year-old male were treated for infectious endocarditis and PTA [152]. Blood cultures grew S. constellatus and $S$. mitis was recovered from the PTA.

\section{Brain abscess}

One case of brain abscess as complication of PTA was found: Sankararaman et al. described a 9-year-old girl with a frontal brain abscess secondary to an ipsilateral PTA [153]. The cerebral abscess was conservatively treated with (undefined) intravenous antibiotics and the patient's condition improved in the days after drainage of the PTA ( $8 \mathrm{~mL}$ of thick pus growing Prevotella species). She developed hydrocephalus requiring an external ventricular drain.

\section{Septic arthritis}

Sever et al. reported a 55-year-old female, who developed septic arthritis of the temporo-mandibular joint and PTA after initial acute tonsillitis [154]. Cultures from both sites of infection grew Staphylococcus haemolyticus. The patient was treated with broad-spectrum antibiotics and PTA drainage. She recovered with an asymptomatic defect in the wall of the external ear canal.

\section{Immunologic reactions \\ Reactive arthritis}

Mazur et al. described a 32-year-old female, who developed poststreptococcal reactive arthritis of the left ankle after initial acute tonsillitis (treated with amoxicillinclavulate for 5 days) and PTA (treated with incision and cefuroxime + metronidazole) [155]. PTA cultures grew Group A streptococci, Prevotella oralis, and Haemophilus parainfluenzae. The patient recovered within 4weeks.

\section{Streptococcal toxic shock syndrome}

One case of Streptococcal toxic shock syndrome complicating a PTA was described [156]: a 68-year-old male developed coagulation disturbances, hypotension, and renal function impairment secondary to a Group A streptococcus-positive PTA. The patient was treated with acute tonsillectomy and broad-spectrum antibiotics. He recovered without sequelae.

\section{Unknown mechanism Kawasaki disease}

Kawasaki disease is a potentially fatal pediatric illness characterized by fever, rash, conjunctivitis, cervical lymphadenopathy, stomatitis, myocarditis, and coronary artery vasculitis. The etiology of the disease is unknown 
and the diagnosis is established by the recognition of five out of six characteristic clinical criteria. Two cases of PTA and Kawasaki disease was found [157, 158]. A 7-year-old boy developed PTA 4 days after finishing a 10-days course of amoxicillin-clavulanate because of Group A streptococcus-positive acute tonsillitis [158]. After initial treatment with incision and intravenous penicillin, the patient developed increasing cervical lymphadenopathy, torticollis, rash, arthritis, acute myocarditis, pleural and pericardial effusions, and heart failure. He was treated with acute tonsillectomy, pericardiocentesis, salisylates, and gamma globulin. He recovered without sequelae. PTA cultures were negative. Another 7-yearold boy was admitted with culture-negative acute tonsillitis and treated with intravenous penicillin [157]. Five days later, PTA was suspected and $1 \mathrm{ml}$ of pus was recovered at time of tonsillectomy. PTA pus cultures were negative. During the next 2 days, he developed classic symptoms of Kawasaki disease, which was treated with salisylates and gamma globulin and the patient recovered.

\section{Limitations}

The majority of cases were described in case reports. Publication bias may influence the relative number of cases for each entity and distort the picture of complications towards more severe cases. Mortality rates could be both over- or underestimated. We were unable to estimate the prevalence of complications to PTA, but it is obviously low. The collected description of the microbiology associated with complicated PTA was limited by different (and often undeclared) culture sites and methods, different levels of species identification and the relatively limited number of cases with thorough description of the bacterial findings. Preceding acute tonsillitis was rather common among patients with complicated PTA and the exact causality of the complications were occasionally difficult to determine, but the initial acute tonsillitis underscores the intimate relationship to PTA, which has previously been questioned by a number of authors [159, 160].

\section{Implications for practice}

It is important for clinicians to acknowledge that a wide range of complications may arise in association with PTA, either simultaneously or after PTA treatment. Complications have been described in PTA patients at all ages, but ages were closely related to complication types (e.g. the median ages were 51-52 years among patients with DM and NF compared to 21 years among patients with LS). We found a pronounced male preponderance $(70 \%)$, which is significantly higher than in uncomplicated PTA (58\%) [5]. The current study stresses that PTA and infectious spread may develop in patients treated with antibiotics (even if surgical drainage is performed) and highlights the importance of thorough patient information at time of discharge, especially in males and $>40$ years of age, who seems to be at increased risk of complications. Improved knowledge on risk factors for complicated disease and the significant pathogens associated with PTA development and further infectious spread are important to reduce the morbidity of throat infections.

\section{Conclusions}

The current study provides an overview of complications of PTA described in the literature within the last 40 years. Complications after spread of bacteria through neck tissues (the major being DM, para- and retropharyngeal abscess, and NF) constituted $77 \%$ of the described cases and other mechanisms of spread were much less frequent (through airway mucosa, 9\%; hematogenous, 13\%; immunologic/unknown, 1\%). In addition to Group A streptococci and F. necrophorum, the current findings suggest that VGS, S. aureus, Prevotella, and Bacteroides may also play occasional roles in the development of PTA as well as spread of infection. Spread of infection could potentially have been avoided in a minority of PTA cases, who presented to health care professionals for the treatment of PTA prior to developing complications. However, the potential for avoidance of complications was difficult to estimate and the majority of patients presented with simultaneous PTA and complication.

\section{Supplementary information}

Supplementary information accompanies this paper at https://doi.
org/10.1186/s12941-020-00375-x.

\section{Additional file 1.}

Abbreviations

PTA: Peritonsillar abscess; NF: Necrotizing fasciitis; DM: Descending mediastinitis; LS: Lemierres syndrome; VGS: Viridans group streptococci.

\section{Acknowledgements}

We thank Padraigh O'leary for English editing.

Authors' contributions

TEK initiating, designing, and drafting of the work; identification and analysis of the studies; accountable for all aspects of the work; TG designing the review; critical revision; accountable for all aspects of the work; MH identification and analysis of the studies; critical revision; accountable for all aspects of the work. All authors read and approved the final manuscript.

\section{Funding}

This work was supported by the Lundbeck Foundation [Grant number: R185-2014-2482]. 


\section{Availability of data and materials}

From references. The full dataset can be obtained from the corresponding author upon request.

\section{Ethics approval and consent to participate Not applicable.}

\section{Consent for publication}

Not applicable.

\section{Competing interests}

None.

\section{Author details}

1 Department of Otorhinolaryngology, Head and Neck Surgery, Aarhus University Hospital, Palle Juul-Jensens Boulevard 99 Aarhus N, Aarhus 8200, Denmark. ${ }^{2}$ Department of Clinical Microbiology, Aarhus University Hospital, Aarhus, Denmark.

Received: 17 May 2020 Accepted: 24 July 2020

Published online: 30 July 2020

\section{References}

1. Klug TE, Rusan M, Fuursted K, Ovesen T. Peritonsillar abscess: complication of acute tonsillitis or weber's glands infection? Otolaryngol Head Neck Surg. 2016;155:199-207. https://doi.org/10.1177/0194599816 639551.

2. Klug TE. Incidence and microbiology of peritonsillar abscess: the influence of season, age, and gender. Eur J Clin Microbiol Infect Dis. 2014;33:1163-7. https://doi.org/10.1007/s10096-014-2052-8.

3. Jousimies-Somer H, Savolainen S, Makitie A, Ylikoski J. Bacteriologic findings in peritonsillar abscesses in young adults. Clin Infect Dis. 1993;16(Suppl 4):S292-8.

4. Klug TE, Henriksen JJ, Rusan M, Fuursted K, Krogfeldt K, Ovesen T, et al. Antibody development to Fusobacterium necrophorum in patients with peritonsillar abscess. Eur J Clin Microbiol Infect Dis. 2014;33:17339. https://doi.org/10.1007/s10096-014-2130-y.

5. Klug TE. Peritonsillar abscess: clinical aspects of microbiology, risk factors, and the association with parapharyngeal abscess. Dan Med J. 2017. 64. pii: B5333.

6. Shaul C, Koslowsky B, Rodriguez M, Schwarz Y, Muahnna N, Peleg U, et al. Is needle aspiration for peritonsillar abscess still as good as we think? A long-term follow-up. Ann Otol Rhinol Laryngol. 2015;124:299304. https://doi.org/10.1177/0003489414556083.

7. Ryan S, Papanikolaou V, Keogh I. Appraisal of the peri-hospital management and evolving microbiology of peritonsillar abscess disease. B-ENT. 2014;10:15-20.

8. Mazur E, Czerwińska E, Korona-Głowniak I, Grochowalska A, KoziołMontewka M. Epidemiology, clinical history and microbiology of peritonsillar abscess. Eur J Clin Microbiol Infect Dis. 2015;34:549-54. https:// doi.org/10.1007/s10096-014-2260-2.

9. Friedman NR, Mitchell RB, Pereira KD, Younis RT, Lazar RH. Peritonsillar abscess in early childhood. Presentation and management. Arch Otolaryngol Head Neck Surg. 1997;123(6):630-2.

10. Brøndbo K, Høie T, Aaløkken M. Peritonsillar abscess in a 2 1/2-monthold infant. J Otolaryngol. 2000;29:119-20.

11. Ormond A, Chao S, Shapiro D, Walner D. Peritonsillar abscess with rapid progression to complete airway obstruction in a toddler. Laryngoscope. 2014;124:2418-21. https://doi.org/10.1002/lary.24770.

12. Gupta N, Lovvorn J, Centor RM. Peritonsilar abscess requiring intensive care unit admission caused by group $\mathrm{C}$ and $\mathrm{G}$ Streptococcus: a case report. Cases J. 2009;2:6808. https://doi.org/10.4076/1757-1626-2-6808.

13. Nagler J, Ruebner RL. Suppurative complications and upper airway obstruction in infectious mononucleosis. J Hosp Med. 2007;2:280-2.

14. Burstin PP, Marshall CL. Infectious mononucleosis and bilateral peritonsillar abscesses resulting in airway obstruction. J Laryngol Otol. 1998;112:1186-8

15. Osculati A, Fassina G. Parapharyngeal abscess and sudden death. Leg Med. 1999;1:34-6.
16. Burtner DD, Goodman M. Anesthetic and operative management of potential upper airway obstruction. Arch Otolaryngol. 1978;104:657-61.

17. Boon C, Wan Mohamad WE, Mohamad I. Bilateral peritonsillar abscess: a rare emergency. Malays Fam Physician. 2018;13:41-4.

18. Lau SK. Sleep apnoea due to bilateral peritonsillar abscess. J Laryngol Otol. 1987;101:617-8.

19. Kessler A, Lapinsky J, Segal S, Berkovitch M. Bilateral peritonsillar abscesses: relief of upper airway obstruction by quinsy tonsillectomy. Isr Med Assoc J. 2003:5:126-7.

20. Hsiao HJ, Huang YC, Hsia SH, Wu CT, Lin JJ. Clinical features of peritonsillar abscess in children. Pediatr Neonatol. 2012;53:366-70. https://doi. org/10.1016/j.pedneo.2012.08.006.

21. Menezes AS, Ribeiro DC, Guimaraes JR, Lima AF, Dias L. Management of pediatric peritonsillar and deep neck infections - cross-sectional retrospective analysis. World J Otorhinolaryngol Head Neck Surg. 2019. https://doi.org/10.1016/j.wjorl.2019.04.003.

22. Parthasarathy $V$, Snyder B, Saddawi-Konefka R. A lot to choke on: case of adult epiglottitis with concurrent peritonsillar abscess in a patient with a sore throat. J Emerg Med. 2018;55:841-4. https://doi.org/10.1016/j. jemermed.2018.09.017.

23. Ito K, Chitose H, Koganemaru M. Four cases of acute epiglottitis with a peritonsillar abscess. Auris Nasus Larynx. 2011;38:284-8. https://doi. org/10.1016/j.anl.2010.06.004.

24. Brandow EC Jr. Immediate tonsillectomy for peritonsillar abscess. Trans Am Acad Ophthalmol Otolaryngol. 1973;77:ORL412-6.

25. Hafidh MA, Sheahan P, Keogh I, Walsh RM. Acute epiglottitis in adults: a recent experience with 10 cases. J Laryngol Otol. 2006;120:310-3.

26. Monobe H, Suzuki S, Nakashima M, Tojima H, Kaga K. Peritonsillar abscess with parapharyngeal and retropharyngeal involvement: incidence and intraoral approach. Acta Otolaryngol Suppl. 2007;559:91-4. https://doi.org/10.1080/03655230701597341.

27. Sichel JY, Attal P, Hocwald E, Eliashar R. Redefining parapharyngeal space infections. Ann Otol Rhinol Laryngol. 2006;115:117-23.

28. Alaani A, Griffiths H, Minhas SS, Olliff J, Lee AB. Parapharyngeal abscess: diagnosis, complications and management in adults. Eur Arch Otorhinolaryngol. 2005;262:345-50.

29. Millar KR, Johnson DW, Drummond D, Kellner JD. Suspected peritonsillar abscess in children. Pediatr Emerg Care. 2007;23:431-8.

30. Page C, Chassery G, Boute P, Obongo R, Strunski V. Immediate tonsillectomy: indications for use as first-line surgical management of peritonsillar abscess (quinsy) and parapharyngeal abscess. J Laryngol Otol. 2010:124:1085-90. https://doi.org/10.1017/S0022215110000903.

31. Thapar A, Tassone P, Bhat N, Pfleiderer A. Parapharyngeal abscess: a lifethreatening complication of quinsy. Clin Anat. 2008;21:23-6.

32. Klug TE, Fischer AS, Antonsen C, Rusan M, Eskildsen H, Ovesen T. Parapharyngeal abscess is frequently associated with concomitant peritonsillar abscess. Eur Arch Otorhinolaryngol. 2014;271:1701-7. https ://doi.org/10.1007/s00405-013-2667-x.

33. Loewen RR, Conley SF, Post AC. An atypical pathway of infection in an adolescent with a deep neck space abscess. Pediatr Dent. 1995:17:220-3.

34. Côrte FC, Firmino-Machado J, Moura CP, Spratley J, Santos M. Acute pediatric neck infections: outcomes in a seven-year series. Int J Pediatr Otorhinolaryngol. 2017;99:128-34. https://doi.org/10.1016/j.ijpor I.2017.05.020.

35. Ohori J, luchi H, Nagano H, Umakoshi M, Matsuzaki H, Kurono Y. The usefulness of abscess tonsillectomy followed by intraoral drainage for parapharyngeal abscess concomitant with peritonsillar abscess in the elderly. Auris Nasus Larynx. 2019. https://doi.org/10.1016/j. anl.2019.06.003.

36. Kawabata M, Umakoshi M, Makise T, Miyashita K, Harada M, Nagano H, Ohori J, Kurono Y. Clinical classification of peritonsillar abscess based on CT and indications for immediate abscess tonsillectomy. Auris Nasus Larynx. 2016:43:182-6. https://doi.org/10.1016/j.anl.2015.09.014.

37. Pedersen MG, Schilthauer O, Vinding HR. [Fatal suppurative dissecting peritonsillar abscess]. Ugeskr Laeger. 1984;146:586. Danish.

38. Young MH, Aronoff DM, Engleberg NC. Necrotizing fasciitis: pathogenesis and treatment. Expert Rev Anti Infect Ther. 2005:3:279-94.

39. Gunaratne DA, Tseros EA, Hasan Z, Kudpaje AS, Suruliraj A, Smith MC, et al. Cervical necrotizing fasciitis: systematic review and analysis of 
1235 reported cases from the literature. Head Neck. 2018;40:2094-102. https://doi.org/10.1002/hed.25184.

40. McMahon J, Lowe T, Koppel DA. Necrotizing soft tissue infections of the head and neck: case reports and literature review. Oral Surg Oral Med Oral Pathol Oral Radiol Endod. 2003;95:30-7.

41. Boninsegna M, Marioni G, Stramare R, Bottin R, Tesei J, de Filippis C, et al. Cervical necrotizing fasciitis: an unusual complication of genuine peritonsillar abscess. J Otolaryngol. 2005;34:258-61.

42. Wills Pl, Vernon RP Jr. Complications of space infections of the head and neck. Laryngoscope. 1981;91:1129-36.

43. Tovi F, Fliss DM, Zirkin HJ. Necrotizing soft-tissue infections in the head and neck: a clinicopathological study. Laryngoscope. 1991;101:619-25.

44. Ialwani AK, Kaplan MJ. Mediastinal and thoracic complications of necrotizing fasciitis of the head and neck. Head Neck. 1991;13:531-9.

45. Greinwald JH Jr, Wilson JF, Haggerty PG. Peritonsillar abscess: an unlikely cause of necrotizing fasciitis. Ann Otol Rhinol Laryngol. 1995;104:133-7.

46. Scott PM, Dhillon RS, McDonald PJ. Cervical necrotizing fasciitis and tonsillitis. J Laryngol Otol. 1994;108:435-7.

47. Jackson BS, Sproat JE. Necrotizing fasciitis of the head and neck with intrathoracic extension. J Otolaryngol. 1995;24:60-3.

48. Hadfield PJ, Motamed M, Glover GW. Synergistic necrotizing cellulitis resulting from peri-tonsillar abscess. J Laryngol Otol. 1996;1 10:887-90.

49. Safak MA, Haberal I, Kiliç D, Göçmen H. Necrotizing fasciitis secondary to peritonsillar abscess: a new case and review of eight earlier cases. Ear Nose Throat J. 2001;80(824-30):833.

50. Maisel RH, Karlen R. Cervical necrotizing fasciitis. Laryngoscope. 1994;104:795-8.

51. Skitarelić N, Mladina R, Matulić Z, Kovacić M. Necrotizing fasciitis after peritonsillar abscess in an immunocompetent patient. J Laryngol Otol. 1999;113:759-61.

52. Djupesland PG. Necrotizing fascitis of the head and neck-report of three cases and review of the literature. Acta Otolaryngol Suppl. 2000:543:186-9.

53. Goldenberg D, Golz A, Netzer A, Flax-Goldenberg R, Joachims HZ. Synergistic necrotizing cellulitis as a complication of peritonsillar abscess. Am J Otolaryngol. 2001;22:415-9.

54. Losanoff JE, Missavage AE. Neglected peritonsillar abscess resulting in necrotizing soft tissue infection of the neck and chest wall. Int I Clin Pract. 2005;59:1476-8

55. Bono G, Argo A, Zerbo S, Triolo V, Procaccianti P. Cervical necrotizing fasciitis and descending necrotizing mediastinitis in a patient affected by neglected peritonsillar abscess: a case of medical negligence. J Forensic Leg Med. 2008;15:391-4. https://doi.org/10.1016/j.jflm.2007.12.008.

56. Andres HT, Hirt R, Statz K, Knipping S. Necrotizing fasciitis due to a peritonsillar abscess. HNO. 2013;61:510-5. https://doi.org/10.1007/s0010 6-012-2582-2.

57. Wolf $H$, Rusan $M$, Lambertsen $K$, Ovesen T. Necrotizing fasciitis of the head and neck. Head Neck. 2010;32:1592-6. https://doi.org/10.1002/ hed.21367.

58. Nielsen HU, Rasmussen N. [Necrotizing fasciitis]. Ugeskr Laeger. 2000;162:1745-7. Danish.

59. Horváth T, Horváth B, Varga Z, Liktor B Jr, Szabadka H, Csákó L, et al. Severe neck infections that require wide external drainage: clinical analysis of 17 consecutive cases. Eur Arch Otorhinolaryngol. 2015;272:346974. https://doi.org/10.1007/s00405-014-3367-x.

60. Krenk L, Nielsen HU, Christensen ME. Necrotizing fasciitis in the head and neck region: an analysis of standard treatment effectiveness. Eur Arch Otorhinolaryngol. 2007;264:917-22.

61. Vaid N, Kothadiya A, Patki S, Kanhere H. Necrotising fasciitis of the neck. Indian J Otolaryngol Head Neck Surg. 2002;54:143-5.

62. Flores CE, Matthews MR, Caruso DM, Foster KN, Stroschein M. A rare case of peritonsillar abscess resulting in cervical necrotizing fasciitis. Otolaryngol Case Rep. 2017;5:1-5.

63. Wenig BL, Shikowitz MJ, Abramson AL Necrotizing fasciitis as a lethal complication of peritonsillar abscess. Laryngoscope. 1984;94:1576-9.

64. Brown L, Yu J, Shi K. Rare case of pan-neck space infection from a peritonsillar abscess. Otolaryngol Head Neck Surg. 2017;157:1 Supplement 1 (P195).

65. Burstin P. Bilateral peritonsillar and parapharyngeal abscesses with cervical necrotizing fasciitis. Aus J Otolaryngol. 1999;3:342-5.
66. Irani BS, Martin-Hirsch D, Lannigan F. Infection of the neck spaces: a present day complication. J Laryngol Otol. 1992;106:455-8. https:// doi.org/10.1017/s0022215100119826.

67. Bovo R, Barillari MR, Martini A. Hospital discharge survey on 4,199 peritonsillar abscesses in the Veneto region: what is the risk of recurrence and complications without tonsillectomy? Eur Arch Otorhinolaryngol. 2016;273:225-30. https://doi.org/10.1007/s0040 5-014-3454-z.

68. Roccia F, Pecorari GC, Oliaro A, et al. Ten years of descending necrotizing mediastinitis: management of 23 cases. J Oral Maxillofac Surg. 2007;65:1716-24.

69. Marty-Ané $\mathrm{CH}$, Berthet JP, Alric $P$, Pegis JD, Rouvière P, Mary $\mathrm{H}$. Management of descending necrotizing mediastinitis: an aggressive treatment for an aggressive disease. Ann Thorac Surg. 1999;68:212-7.

70. Freeman RK, Vallières E, Verrier ED, Karmy-Jones R, Wood DE. Descending necrotizing mediastinitis: an analysis of the effects of serial surgical debridement on patient mortality. J Thorac Cardiovasc Surg. 2000;119:260-7.

71. Papalia E, Rena O, Oliaro A, Cavallo A, Giobbe R, Casadio C, et al. Descending necrotizing mediastinitis: surgical management. Eur J Cardiothorac Surg. 2001;20:739-42.

72. Makeieff M, Gresillon N, Berthet JP, Garrel R, Crampette L, Marty-Ane C, Guerrier B. Management of descending necrotizing mediastinitis. Laryngoscope. 2004;114:772-5.

73. Mora R, Jankowska B, Catrambone U, Passali GC, Mora F, Leoncini G, Passali FM, Barbieri M. Descending necrotizing mediastinitis: ten years' experience. Ear Nose Throat J. 2004;83(774):776-80.

74. Civen R, Väisänen ML, Finegold SM. Peritonsillar abscess, retropharyngeal abscess, mediastinitis, and nonclostridial anaerobic myonecrosis: a case report. Clin Infect Dis. 1993;16(Suppl 4):S299-303.

75. Alsoub H, Chacko KC. Descending necrotising mediastinitis. Postgrad Med J. 1995;71:98-101.

76. Sancho LM, Minamoto H, Fernandez A, Sennes LU, Jatene FB. Descending necrotizing mediastinitis: a retrospective surgical experience. Eur J Cardiothorac Surg. 1999:16:200-5.

77. Lautermann J, Lehnerdt G, Beiderlinden M, Sudhoff H. Infections of the deep neck spaces with accompanying mediastinitis. Laryngorhinootologie. 2005;84:171-5.

78. Mihos PT, Gakidis I, Potaris K, Stathopoulou S. Tonsillitis, descending necrotizing mediastinitis, and a different neck drainage. Am J Otolaryngol. 2006;27:341-3.

79. Collin J, Beasley N. Tonsillitis to mediastinitis. J Laryngol Otol. 2006;120:963-6.

80. Sandner A, Börgermann J, Kösling S, Bloching MB. Descending necrotizing mediastinitis" due to deep neck infections Incidence and management. HNO. 2006;54:861-7.

81. Kinzer S, Maier W, Ridder GJ. Peritonsillar abscess: a life threatening disease-diagnostic and therapeutic aspects. Laryngorhinootologie. 2007:86:371-5.

82. Geerts JW, van Driel EM, Janssen MJ. Descending mediastinitis in Epstein-Barr virus infection. J Clin Microbiol. 2015;53:1781-2. https:// doi.org/10.1128/JCM.03578-14.

83. De Freitas RP, Fahy CP, Brooker DS, Primrose WJ, McManus KG, McGuigan JA, et al. Descending necrotising mediastinitis: a safe treatment algorithm. Eur Arch Otorhinolaryngol. 2007:264:181-7.

84. Vural FS, Girdwood RW, Patel AR, Zigiriadis E. Descending mediastinitis. Asian Cardiovasc Thorac Ann. 2012;20:304-7. https://doi. org/10.1177/0218492311434088

85. Palma DM, Giuliano S, Cracchiolo AN, Falcone M, Ceccarelli G, Tetamo $R$, et al. Clinical features and outcome of patients with descending necrotizing mediastinitis: prospective analysis of 34 cases. Infection. 2016:44:77-84. https://doi.org/10.1007/s15010-015-0838-y.

86. Misthos P, Katsaragakis S, Kakaris S, Theodorou D, Skottis I. Descending necrotizing anterior mediastinitis: analysis of survival and surgical treatment modalities. J Oral Maxillofac Surg. 2007;65:635-9.

87. Mihos P, Potaris K, Gakidis I, Papadakis D, Rallis G. Management of descending necrotizing mediastinitis. J Oral Maxillofac Surg. 2004;62:966-72.

88. Cordero L, Torre W, Freire D. Descending necrotizing mediastinitis and respiratory distress syndrome treated by aggressive surgical treatment. J Cardiovasc Surg. 1996;37:87-8. 
89. Zgheib A, el Allaf D, Demonty J, Rorive G. Intrathoracic infections with bacteraemia due to Eikenella corrodens as a complication of peritonsillar abscesses: report of a case and review of the literature. Acta Clin Belg. 1992;47:124-8

90. Laxmipathi G, Mahendra N, Kumar V. Uncommon complication of quinsy. Indian J Otolaryngol Head Neck Surg. 2003;55:289-91. https:// doi.org/10.1007/BF02992443.

91. Nielsen TR, Clement F, Andreassen UK. Mediastinitis-a rare complication of a peritonsillar abscess. J Laryngol Otol. 1996;110:175-6.

92. Sokouti M, Nezafati S. Descending necrotizing mediastinitis of oropharyngeal infections. J Dent Res Dent Clin Dent Prospects. 2009;3:825. https://doi.org/10.5681/joddd.2009.021.

93. Endo S, Murayama F, Hasegawa T, Yamamoto S, Yamaguchi T, Sohara $Y$, et al. Guideline of surgical management based on diffusion of descending necrotizing mediastinitis. Jpn J Thorac Cardiovasc Surg. 1999;47:14-9.

94. Iyer AP, Kugathasan G, Prabha R, Malik P, Kuteyi O, Larbalestier R. Descending mediastinitis managed by sternotomy, taurolidine and delayed closure. Asian Cardiovasc Thorac Ann. 2013;21:612-4. https:// doi.org/10.1177/0218492312459045.

95. Wahab D, Bichard J, Shah A, Mann B. Just a sore throat? Uncommon causes of significant respiratory disease. BMJ Case Rep. 2013. https:// doi.org/10.1136/bcr-2013-008739.

96. Manecke GR Jr, Marghoob S, Finzel KC, Madoff DC, Quijano IH, Poppers PJ. Catastrophic caudad spread of a peritonsillar abscess: a case report. Anesthesiology. 1999;91:1956-8.

97. Asrar L, Raza SS, Ali S, Mohammad R, Khan S. Segmental lower lobe collapse of the left lung associated with mediastinitis secondary to parapharyngeal abscess and quinsy. J Otolaryngol. 2004;33:260-3.

98. Gallo O, Deganello A, Meccariello G, Spina R, Peris A. Vacuum-assisted closure for managing neck abscesses involving the mediastinum. Laryngoscope. 2012;122:785-8. https://doi.org/10.1002/lary.22403.

99. Corsten MJ, Shamji FM, Odell PF, Frederico JA, Laframboise GG, Reid KR, Vallieres E, Matzinger F. Optimal treatment of descending necrotising mediastinitis. Thorax. 1997:52:702-8.

100. Nakamura Y, Matsumura A, Katsura H, Sakaguchi M, Ito N, Kitahara N, et al. Successful video-thoracoscopic drainage for descending necrotizing mediastinitis. Gen Thorac Cardiovasc Surg. 2009;57:111-5. https:// doi.org/10.1007/s11748-008-0328-6.

101. Cho JS, Kim YD, Hoseok I, Lee SK, Jeong YJ. Treatment of mediastinitis using video-assisted thoracoscopic surgery. Eur J Cardio-Thoracic surg. 2008:4(3):520-4.

102. Anderson AR, Gill P, Moor J, Telfer MR. Pyothorax resulting from peritonsillar abscess. Int J Clin Pract. 2010;64:105-6. https://doi.org/10.111 1/j.1742-1241.2006.00883.x.

103. Sakai T, Matsutani N, Ito K, Mochiki M, Mineda J, Shirai S, et al. Deep cervical and paratracheal drainage for descending necrotizing mediastinitis. Asian Cardiovas Thor Annals. 2020;28:29-32.

104. Yanik F, Karamustafaoglu YA, Yoruk Y. Management of a difficult infectional disease: descending necrotizing mediastinitis. J Inf Develop Count. 2018;12:748-54.

105. Garino JP, Ryan TJ. Carotid hemorrhage: a complication of peritonsillar abscess. Am J Emerg Med. 1987:5:220-3.

106. Blum DJ, McCaffrey TV. Septic necrosis of the internal carotid artery: a complication of peritonsillar abscess. Otolaryngol Head Neck Surg. 1983;91(2):114-8

107. da Silva PS, Waisberg DR. Internal carotid artery pseudoaneurysm with life-threatening epistaxis as a complication of deep neck space infection. Pediatr Emerg Care. 2011;27:422-4. https://doi.org/10.1097/ PEC.0b013e3182187539.

108. Kleemann D, Dinsel S, Radtke A. Mycotic aneurysm of the internal carotid artery. Laryngorhinootologie. 2008;87:878-81. https://doi. org/10.1055/s-2008-1077388.

109. Stevens HE. Vascular complication of neck space infection: case report and literature review. J Otolaryngol. 1990;19:206-10.

110. Conrad R, Krokenberger M, Hufen V, Harder T. Pseudoaneurysm of the internal carotid artery following a peritonsillar abscess. Aktuelle Radiol. 1994:4:109-11.

111. Mootz W, Bleif H. Internal carotid artery aneurism following peritonsillar abscess (author's transl). HNO. 1980;28:197-200.
112. Reiss M, Reiss G. Unusual complications of a bilateral peritonsillar abscess. Praxis. 1999;88:1404-6.

113. Hidaka H, Ishida E, Suzuki T, Matsutani S, Kobayashi T, Takahashi S. Unusual parapharyngeal extension of peritonsillar abscess to the masticator space: successfully drained by extraoral and intraoral endoscopic approaches. Ann Otol Rhinol Laryngol. 2014;123:333-7. https://doi. org/10.1177/0003489414526360.

114. Riordan T. Human infection with Fusobacterium necrophorum (Necrobacillosis), with a focus on Lemierre's syndrome. Clin Microbiol Rev. 2007;20:622-59.

115. Seidenfeld SM, Sutker WL, Luby JP. Fusobacterium necrophorum septicemia following oropharyngeal infection. JAMA. 1982;248:1348-50.

116. Escher R, Haltmeier S, von Steiger N, Dutly AE, Arnold A, Kickuth R, Schiemann U. Advanced Lemierre syndrome requiring surgery. Infection. 2008;36:495-6. https://doi.org/10.1007/s15010-008-8216-7.

117. Righini CA, Karkas A, Tourniaire R, N'Gouan JM, Schmerber S, Reyt E, et al. Lemierre syndrome: study of 11 cases and literature review. Head Neck. 2014;36:1044-51. https://doi.org/10.1002/hed.23410.

118. Kuppalli K, Livorsi D, Talati NJ, Osborn M. Lemierre's syndrome due to Fusobacterium necrophorum. Lancet Infect Dis. 2012;12:808-15. https ://doi.org/10.1016/S1473-3099(12)70089-0.

119. Holm K, Svensson PJ, Rasmussen M. Invasive Fusobacterium necrophorum infections and Lemièrre's syndrome: the role of thrombophilia and EBV. Eur J Clin Microbiol Infect Dis. 2015;34:2199-207. https://doi. org/10.1007/s10096-015-2469-8.

120. Rebelo J, Nayan S, Choong K, Fulford M, Chan A, Sommer DD. To anticoagulate? Controversy in the management of thrombotic complications of head \& neck infections. Int J Pediatr Otorhinolaryngol. 2016;88:12935. https://doi.org/10.1016/j.jporl.2016.06.013.

121. David H. A 21-year-old man with fever and abdominal pain after recent peritonsillar abscess drainage. Am J Emerg Med. 2009;27(515):e3-4. https://doi.org/10.1016/j.ajem.2008.07.043.

122. Westhout F, Hasso A, Jalili M, Afghani B, Armstrong W, Nwagwu C, et al. Lemierre syndrome complicated by cavernous sinus thrombosis, the development of subdural empyemas, and internal carotid artery narrowing without cerebral infarction. J Neurosurg. 2007;106:53-6.

123. Takeda K, Kenzaka T, Morita Y, Kuroki S, Kajii E. A rare case of Lemierre`s syndrome caused by Porphyromonas asaccharolytica. Infection. 2013;41:889-92. https://doi.org/10.1007/s15010-013-0421-3.

124. Nakayama M, Tabuchi K, Nomura M, Murashita H, Komeno M, Yamaguchi T, et al. Thrombophlebitis of the head and neck: report of two cases. Auris Nasus Larynx. 2010;37:651-5. https://doi.org/10.1016/j. anl.2009.12.006

125. Jones C, Siva TM, Seymour FK, O'Reilly BJ. Lemierre's syndrome presenting with peritonsillar abscess and VIth cranial nerve palsy. J Laryngol Otol. 2006;120:502-4

126. Raggio BS, Grant MC, Rodriguez K, Cripe PJ. Neonatal Lemierre Syndrome: youngest Reported Case and Literature Review. Clin Pediatr. 2018:57:294-9. https://doi.org/10.1177/0009922817721156.

127. Ridgway JM, Parikh DA, Wright R, Holden P, Armstrong W, Camilon F, et al. Lemierre syndrome: a pediatric case series and review of literature. Am J Otolaryngol. 2010;31:38-45. https://doi.org/10.1016/j.amjot 0.2008 .09 .006

128. Weeks DF, Katz DS, Saxon P, Kubal WS. Lemierre syndrome: report of five new cases and literature review. Emerg Radiol. 2010;17:323-8. https:// doi.org/10.1007/s10140-010-0858-y.

129. Ehrenfried Berthelsen R, Hein L. Lemierre's syndrome following peritonsillar abscess. Ugeskr Laeger. 2012;174:1534-5.

130. Gutzeit A, Roos JE, Portocarrero-Fäh B, Reischauer C, Claas L, Gassmann $\mathrm{K}$, et al. Differential diagnosis of Lemierre's syndrome in a patient with acute paresis of the abducens and oculomotor nerves. Korean J Ophthalmol. 2013;27:219-23. https://doi.org/10.3341/kjo.2013.27.3.219.

131. Ledochowski S, Freichet M, Wallet F, Friggeri A. Lemierre's syndrome: when a contralateral thrombosis stirs the debate. Intensive Care Med. 2015;41:329-30. https://doi.org/10.1007/s00134-014-3511-5.

132. Alperstein A, Fertig RM, Feldman M, Watford D, Nystrom S, Delva G, et al. Septic thrombophlebitis of the internal jugular vein, a case of Lemierre's syndrome. Intractable Rare Dis Res. 2017;6:137-40. https:// doi.org/10.5582/irdr.2017.01021. 
133. Edelman K, Pedram S, Grinnan D. Lemierre's syndrome due to arcanobacterium haemolyticum: a case report. Chest Infect. 2017. https://doi. org/10.1378/chest.1383657.

134. Cota D, Zee J. A fatal complication of retropharyngeal abscess. Crit Care Med. 2016:44:12. https://doi.org/10.1097/01.ccm.0000510665.36211.20.

135. Hagelskjaer Kristensen L, Prag J. Lemierre's syndrome and other disseminated Fusobacterium necrophorum infections in Denmark: a prospective epidemiological and clinical survey. Eur J Clin Microbiol Infect Dis. 2008;27:779-89. https://doi.org/10.1007/s10096-008-0496-4.

136. Weesner CL, Cisek JE. Lemierre syndrome: the forgotten disease. Ann Emerg Med. 1993;22:256-8.

137. Hansberry DR, D'Angelo M, Prabhu AV, White MD, Tilwa S, Li Z et al. Lemierre's syndrome: Acute oropharyngeal infection leading to septic thrombophlebitis of the internal jugular vein with pulmonary septic emboli. Interdiscip Neurosurg. 2000; 100573.

138. Zea-Hernandez J, Arens R. A rare case of lemierre's syndrome caused by prevotella oris. Am J Resp Crit Care Med. 2015;191 MeetingAbstracts.

139. Schubert AD, Hotz M-A, Caversaccio MD, Arnold A. Septic thrombosis of the internal jugular vein: lemierre's syndrome revisited. Laryngoscope. 2015:125:863-8

140. Jacobs R, Toklu B. Lemierre's syndrome: Recalling the "forgotten disease". J Gen Int Med. 2012;27(2):S450-S451.

141. Meles K, Hopkins A, Rathore M. A retrospective chart review on cases of lemierre's syndrome in a tertiary care childrens hospital. J Invest Med. 2012;60:371-2.

142. Chircop C, Mallia M, Aquilina J. Rare presentations of the "Forgotten Disease". J Neurol. 2011;258(1):S245.

143. Klug TE, Henriksen JJ, Fuursted K, Ovesen T. Significant pathogens in peritonsillar abscesses. Eur J Clin Microbiol Infect Dis. 2011;30:619-27.

144. Klug TE, Rusan M, Fuursted K, Ovesen T, Jorgensen AW. A systematic review of Fusobacterium necrophorum-positive acute tonsillitis: prevalence, methods of detection, patient characteristics, and the usefulness of Centor Score. Eur J Clin Microbiol Infect Dis. 2016;35:1903-12.

145. Shah S, Shah K, Yalamanchii K. A rare case of fusobacterium necrophorum bacteremia in the setting of quinsy. Criti Care Med. 2016. https:// doi.org/10.1097/10.ccm.0000510461.43450.2d.

146. Halfman C, Joslin J. Fusobacterium necrophum without septic thrombophlebitis. Crit Care Med. 2016. https://doi.org/10.1097/01.ccm.00005 10447.95922.2a

147. Pericleous A, Wilkinson S, Gerrish A, Daniel M. Peritonsillar abscess in an infant with congenital bone marrow failure. Int J Pediatr Otorhinolaryngol. 2019;124:200-2. https://doi.org/10.1016/j.ijporl.2019.05.037.

148. Yamada K, Hashimoto K, Tsubokawa T, Tashiro K, Ohmura S, Taniguchi T, Shibata K. Respiratory failure caused by massive pleural effusion in a patient with deep neck abscess. J Anesth. 2004;18:48-50.
149. Oleske JM, Starr SE, Nahmias AJ. Complications of peritonsillar abscess due to Fusobacterium necrophorum. Pediatrics. 1976;57:570-1.

150. Dickson RI, Roberts FJ, Frederick FJ. Fatal myocarditis associated with peritonsillar abscess. Laryngoscope. 1983;93:565-7.

151. Dressler J, Berberich A, Hüttenbrink KB, Müller E. Pancarditis as cause of death after abscess tonsillectomy. Laryngorhinootologie. 2004;83:593-6.

152. Lau MJ, Shenoy A. A case of infectious endocarditis caused by streptococcus constellatus. Am J Resp Crit Care Med. 2018;197:Meeting Abstracts.

153. Sankararaman S, Riel-Romero RM, Gonzalez-Toledo E. Brain abscess from a peritonsillar abscess in an immunocompetent child: a case report and review of the literature. Pediatr Neurol. 2012;47:451-4. https ://doi.org/10.1016/j.pediatrneurol.2012.08.014.

154. Araz Server E, Onerci Celebi O, Hamit B, Yigit O. A rare complication of tonsillitis: septic arthritis of the temporomandibular joint. Int J Oral Maxillofac Surg. 2017:46:1118-20. https://doi.org/10.1016/j. ijom.2017.04.007.

155. Mazur E, Czerwińska E, Grochowalska A, Kozioł-Montewka M. Concurrent peritonsillar abscess and poststreptococcal reactive arthritis complicating acute streptococcal tonsillitis in a young healthy adult: a case report. BMC Infect Dis. 2015;15:50. https://doi.org/10.1186/s1287 9-015-0780-8.

156. Aalling M, Klug TE. Streptococcal toxic shock syndrome complicating a peritonsillar abscess. Infect Dis. 2015;47:101-3. https://doi org/10.3109/00365548.2014.961543.

157. Ravi KV, Brooks JR. Peritonsillar abscess-an unusual presentation of Kawasaki disease. J Laryngol Otol. 1997;111:73-4.

158. Rothfield RE, Arriaga MA, Felder H. Peritonsillar abscess in Kawasaki disease. Int J Pediatr Otorhinolaryngol. 1990;20:73-9.

159. Passy V. Pathogenesis of peritonsillar abscess. Laryngoscope. 1994;104:185-90

160. Kordeluk S, Novack L, Puterman M, Kraus M, Joshua BZ. Relation between peritonsillar infection and acute tonsillitis: myth or reality? Otolaryngol Head Neck Surg. 2011;145:940-5.

\section{Publisher's Note}

Springer Nature remains neutral with regard to jurisdictional claims in published maps and institutional affiliations.
Ready to submit your research? Choose BMC and benefit from:

- fast, convenient online submission

- thorough peer review by experienced researchers in your field

- rapid publication on acceptance

- support for research data, including large and complex data types

- gold Open Access which fosters wider collaboration and increased citations

- maximum visibility for your research: over $100 \mathrm{M}$ website views per year

At $\mathrm{BMC}$, research is always in progress.

Learn more biomedcentral.com/submissions 